\title{
The Students' Attitude to the Social Environment of the University: Cross-Cultural Aspect
}

\author{
Elena Viktorovna Noskova ${ }^{1}$ \& Irina Matveevna Romanova ${ }^{1}$ \\ ${ }^{1}$ Far Eastern Federal University, Vladivostot, Russian Federation \\ Correspondence: Elena Viktorovna Noskova \& Irina Matveevna Romanova, Suhanova Street 8, Vladivostok, \\ 690950, Russian Federation. E-mail: noskova.ev@dvfu.ru; romanova.im@dvfu.ru
}

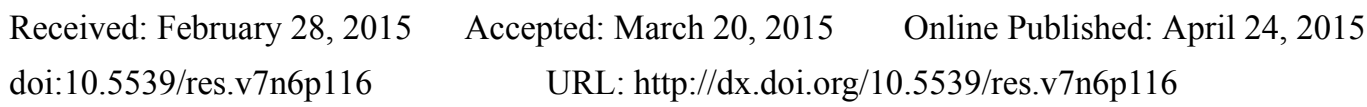

\begin{abstract}
The article notes that increasing the international competitiveness of the university requires the consideration of many factors, including the social environment of the university. The purpose of this study is to develop a methodological approach to assess the impact of cross-cultural features on the students' attitude toward the social environment of the university as a factor of its international competitiveness. In this study we developed a model of culture that reflects a list of cultural values, the characteristics of the material and institutional environment, which are adapted to the market of educational services of universities. We highlighted the elements of the social infrastructure of the university: housing and utilities, public catering and trade, consumer services, cultural and recreational, sports and fitness, communication. The proposed methodological approach was tested on Chinese and Russian students. The results of the study can be used to develop measures to improve the international competitiveness of the universities.
\end{abstract}

Keywords: social media, cross-culture, model of culture, competitiveness of the university

\section{Introduction}

Modern universities form and develop human capital, and the international competitiveness of the country largely depends on it. The growing cross-country competition determines the need to find new sources of increasing the competitiveness of the universities. The competitiveness of universities is considered in modern science from different positions. A content analysis of 186 international publications in the past five years has allowed to allocate the following actual trends in studying the competitiveness of universities: international university rankings; the formation of world-class universities; universities as research corporations; university's cooperation with the business environment; the impact of universities on the development of a specific territory; university management systems; innovation activity of universities; information and communication technologies in education; student migration; the process of educational activities in universities; employment of students and graduates; social environment of the universities and so on. In this study, the authors attempted to estimate the students' attitude to the social environment of the University as a factor of its competitiveness.

International competitiveness of the universities, the factors determining it, including the social environment of the universities, is analyzed in the following works (Aghion et al., 2010; Buela-Casal et al., 2007; deFilippo et al., 2012; Dill et al., 2005; Filinov et al., 2002 ; Glänzel et al., 2002; Li et al., 2005; Harvey, 2008; Liu et al., 2005; Merisotiset, 2005; Mohrman, 2013; Mok et al., 2011; Mok, 2014; Rodionov et al., 2014; Yaşar et al., 2012; Yonezawa et al., 2002). The works of Barlett, 2011 cover the studying of students' catering as an element of the social environment. The advantage of this study is the consideration of the social environment of the University in a cross-cultural context. The problems of cross-cultural researches are reflected in the following works (Agarwal et al., 2010; Hyari et al., 2012; Cheung et al., 2011; Dimitrova et al., 2014; Gelade, 2008; Gestel, 2012; Harrison, 2006; Hofstede et al., 2002; Redden et al., 2011; Sankaran et al., 2011; Yousaf et al., 2013).

The analysis of the publications above showed the absence of a common approach to the assessment of the social environment of the universities: some elements of the social environment are not covered, factors affecting its formation and development are not analyzed, the problems of cross-cultural analysis of students' attitude to the social environment of the University are poorly studied, although their relevance increases with the increasing of international competitiveness of the universities. All this indicates the relevance of the research topic and the lack of its study. 


\section{Methodology}

The purpose of the study is to highlight the determinants of the social infrastructure of the University, to determine their importance for the students in the context of cross-cultural analysis.

1) Statement of the problem:

- A problem that requires a research - to find gaps in the Russian and Chinese students' attitude to the social environment of the University.

- A problem to solve-increasing the international competitiveness of the universities by developing their social environment.

2) Defining the objectives of the study

According to the purpose, this research project states the following tasks:

- To consider the model of culture and to identify its components;

- To identify the main elements of the social environment of universities;

- To assess the factors affecting the formation and development of the social environment of the universities

- To determine the effect of cross-cultural features of the students' behavior on their attitude to the social environment of the universities.

3) The formation of the basic hypotheses of the study

Hypothesis 1: The model of the culture is formed under the influence of the system of cultural values, and the elements of the institutional and material environments.

Hypothesis 2: The students' attitude (of different cultures) to the social environment of the universities depends on the model of the culture of a particular country

4) Determining the type of the research project

Exploration study, using appropriate empirical methods the suggested hypothesis are confirmed (refuted).

5) The object of the study is the students' attitude to the social environment of the universities, the subject of the study is - cross-cultural features of the students' behavior in relation to the social environment of the universities.

6) Methods of research: desk and field research using quantitative and qualitative methods of data collection. Main directions of the research:

- Studying the cultural values (Kuznetsov, 2010) (Table 1);

Table 1. Characteristics of cultural values

\begin{tabular}{ll}
\hline Group & List \\
\hline Individual values of life & $\begin{array}{l}\text { Health, work, family life, friends, freedom, development, active energetic life, } \\
\text { entertainment, financially secure life, self-confidence, security }\end{array}$ \\
Ethical values & $\begin{array}{l}\text { Honesty, irreconcilability to shortcomings, beauty, manners, cheerfulness, } \\
\text { responsibility, efficiency, attention }\end{array}$ \\
$\begin{array}{l}\text { Values } \\
\text { self-affirmation } \\
\text { Intellectual values }\end{array}$ & $\begin{array}{l}\text { High demands, independence, courage, strong will } \\
\text { Education, rationalism, self-control, breadth of views }\end{array}$ \\
\hline
\end{tabular}

- Studying the institutional environment (Table2) 
Table 2. Characteristics of the institutional environment taking into account the features of the education market

\begin{tabular}{ll}
\hline Group & List \\
\hline $\begin{array}{l}\text { Political and legal } \\
\text { regulation }\end{array}$ & $\begin{array}{l}\text { The level of influence of the geopolitical situation in the world (region) on } \\
\text { the university's choice } \\
\text { The level of diplomatic relations between your country and other countries } \\
\text { The level of political stability in the country } \\
\text { The level and quality of the population's life; } \\
\text { The level of state regulation in the sphere of education } \\
\text { The level of the influence of the population's religion on the offer of } \\
\text { educational services } \\
\text { The level of the influence of religious restrictions on the consumption of } \\
\text { educational services }\end{array}$ \\
\end{tabular}

- Studying the material environment (Table3)

Table 3. Characteristics of the material environment taking into account the features of the education market

\begin{tabular}{ll}
\hline Group & List \\
\hline \multirow{3}{*}{$\begin{array}{l}\text { Scientific technological } \\
\text { environment }\end{array}$} & $\begin{array}{l}\text { The level of the development of technological and scientific environment in } \\
\text { the country } \\
\text { The level of universities supply } \\
\text { The level of using modern technologies and equipment in universities }\end{array}$ \\
natural resources & Geographical position of the University \\
Economic Environment & The level of economic development of the country \\
\hline
\end{tabular}

7) A sources of secondary information. In order to work up tools for field researches it is necessary to conduct a content analysis of secondary information on the problem under study. As sources of secondary information we encourage to consider the print and electronic, business and specialized publications; industry literature; Internet resources; Analytical reviews in press. The result of the analysis of secondary information is to distinguish the basic elements of the social environment of the universities (housing and communal infrastructure, infrastructure, trade and public catering, domestic service infrastructure, cultural and recreational infrastructure, communicational infrastructure) and the development of a list of questions to determine the students' attitude to the elements of the social environment (Table 4)

8) Collecting primary information. The sources of primary information are the results of a questionnaire survey of Russian and Chinese students. The purpose of the questionnaire is to obtain quantitative estimates to link the elements of culture and students' attitude to the social environment of the universities.

9) Determination of sample size. In forming the sample we took into account the age and education of the students, and their nationality. The sample included Russian and Chinese students; the sample size was 520 people.

10) Data analysis. The obtained results of the survey were processed by statistical methods by constructing matrixes of conjugate of the elements of culture and students' attitude to the social environment of the universities. The respondents' answers were expressed on a scale of 1 to 5 , where 1 is the least important indicator for the respondent, 5 is the most important. 
Table 4. Characteristics of the elements of the social environment of the universities

\begin{tabular}{|c|c|}
\hline $\begin{array}{l}\text { Elements of the social } \\
\text { environment }\end{array}$ & \\
\hline $\begin{array}{l}\text { Housing and communal } \\
\text { infrastructure }\end{array}$ & $\begin{array}{l}\text { The presence of a hostel: } \\
\text { The presence of a hotel: }\end{array}$ \\
\hline $\begin{array}{l}\text { Trade and public catering } \\
\text { infrastructure }\end{array}$ & $\begin{array}{l}\text { The presence of canteens in every university building } \\
\text { The presence of canteens in every hostel } \\
\text { The presence of a canteen in the campus } \\
\text { The presence of a restaurant in the campus } \\
\text { The presence of outlets selling food (drinks, cakes, etc.) In each university } \\
\text { building/hostel } \\
\text { The presence of coffee vending machines in each university building / hostel } \\
\text { The presence of snack machines (selling drinks, snacks) in each university } \\
\text { building/hostel } \\
\text { The presence of food outlets on campus } \\
\text { The presence of a shop selling business and literature on campus } \\
\text { The presence of sales outlet for the sale of office supplies on campus } \\
\text { The presence of copy centers on campus } \\
\text { The presence of a pharmacy on campus } \\
\text { The presence of vending machines for the sale of contact lenses and accessories } \\
\text { on campus } \\
\text { The presence of a shop selling flowers on campus } \\
\text { The presence of shops for cellular communications on campus } \\
\text { The presence of sales outlet on campus to sell air, railway and bus tickets }\end{array}$ \\
\hline $\begin{array}{l}\text { Domestic } \\
\text { infrastructure }\end{array}$ & $\begin{array}{l}\text { The presence of tailoring shop on campus } \\
\text { The presence of shoe repair post on campus } \\
\text { The presence of dry cleaning posts on campus } \\
\text { The presence of a photo studio on campus } \\
\text { The presence of hair and beauty salon on campus } \\
\text { The presence of rental posts for bikes, scooters, skates, etc. } \\
\text { The presence of security guards on campus }\end{array}$ \\
\hline $\begin{array}{l}\text { Cultural and recreational } \\
\text { infrastructure }\end{array}$ & $\begin{array}{l}\text { The presence of museums on campus } \\
\text { The presence of cinemas on campus } \\
\text { The presence of a theater on campus } \\
\text { The presence of entertainment center (billiards, bowling, etc.) on campus } \\
\text { The presence of concert halls } \\
\text { The presence of exhibition and congress facilities } \\
\text { The presence of a botanical garden on campus } \\
\text { The presence of parkland on campus } \\
\text { The presence of the embankment on campus } \\
\text { The presence of a beach on campus }\end{array}$ \\
\hline
\end{tabular}


The presence of stadiums (volleyball, basketball, football, tennis courts) on campus

The presence of gyms

The presence of pools Sport and recreation The presence of the ski slopes
infrastructure

The presence of an indoor skating rink

The presence of university's sanatorium, preventorium

The presence of a university's clinic on campus

The presence of a a medical post on campus

The level of transport infrastructure development on campus

The presence of car parking on campus

The presence of the Internet

The presence of the telephone network

Communicational

infrastructure

The presence of call-center on campus (call processing)

The presence of contact centers (processing of communication by electronic and ordinary mail, fax) on campus

The presence of post offices on campus

The presence of facilities that provide services for the express delivery of documents and goods on campus

The presence of a students' radio

The presence of a students' television broadcasting

\section{Results}

On the basis of the developed methodological approach and tools, the authors conducted a questionnaire survey of Chinese and Russian students, the results of which allowed determining the impact of the features of the culture of the analyzed countries on the students' attitude to the social environment of the universities, which is an important factor of their competitiveness. In the survey, respondents obtained estimates of cultural values, elements of the institutional and financial environment, which in turn form the model of culture.

The obtained estimates of cultural values of two different cultures (China and Russia) indicate that in general, the analyzed values are largely important for all respondents (Figure 1).

We should note that for Russian students the most important values are independence, cheerfulness, honesty, development and breadth of views; the least important-irreconcilability to shortcomings, high demands and self-control. For Chinese students the most important values are-health, family life and security; the least important - beauty, rationalism, irreconcilability to shortcomings. Minimum gaps in assessing the cultural values by representatives of different cultures are observed in such important values as work, development, financially secure life, honesty. 


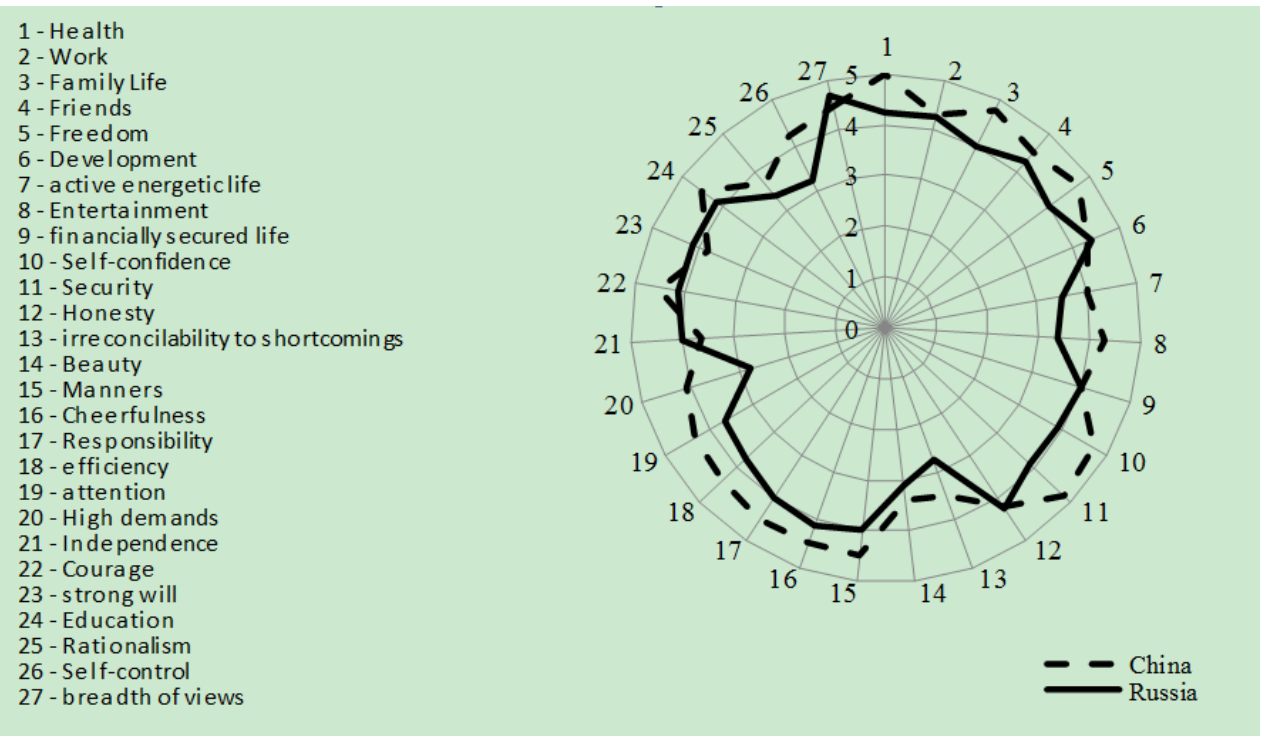

Figure 1. Distribution of the average scores of the respondents based on the importance of cultural values in the formation of the culture model, authoring

Institutional environment is characterized by more significant gaps in the estimates of the respondents compared to cultural values (Figure 2).

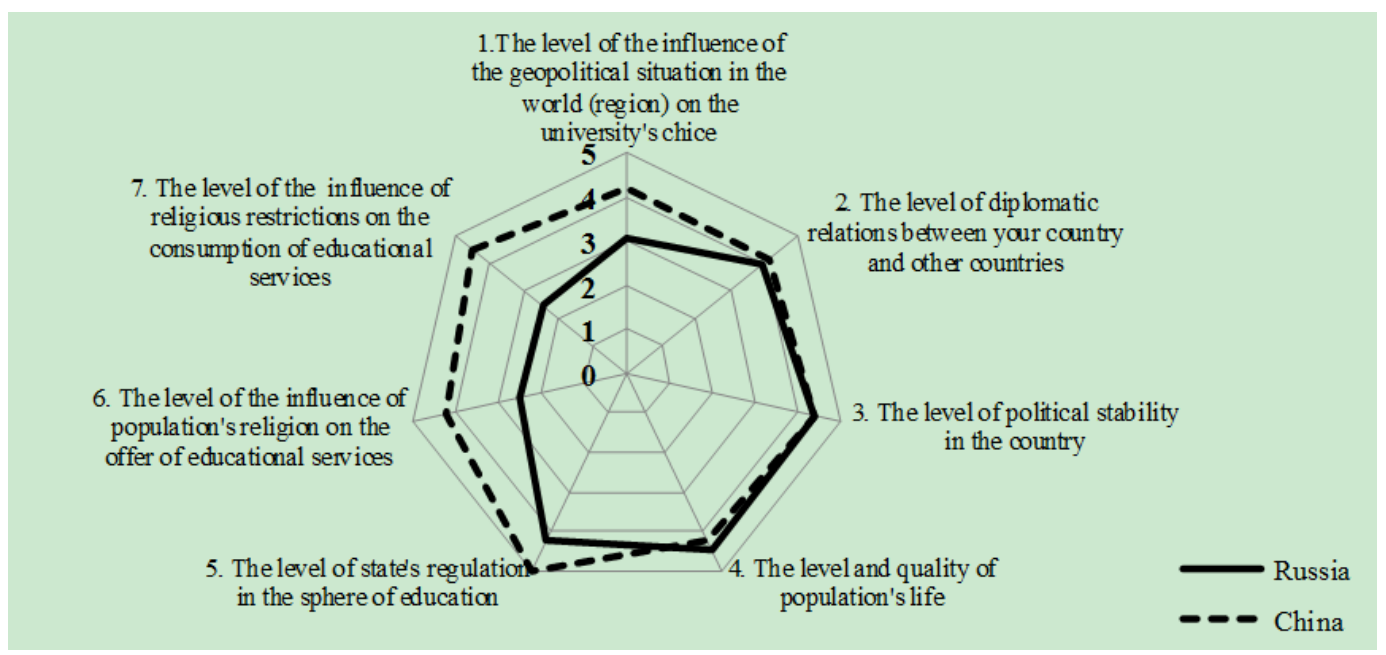

Figure 2. The distribution of the average scores of the respondents concerning the importance of the elements of the institutional environment in the shaping of the cultural model, authoring

The largest gaps are observed in the influence of religious restrictions on the supply and consumption of educational services. This indicator is important for Chinese students (grades in the range of 4.25-4.5 points) and unimportant for Russian students (grades 2.45-2.5 points). The level of the state regulation in the education sphere, the level and quality of the population's life, the level of political stability in the country are important indicators for the representatives of the Russian and Chinese culture.

Estimates of the material environment among respondents of Russia and China are not significantly different, and have high values (3.8-4.7) (Figure 3). 


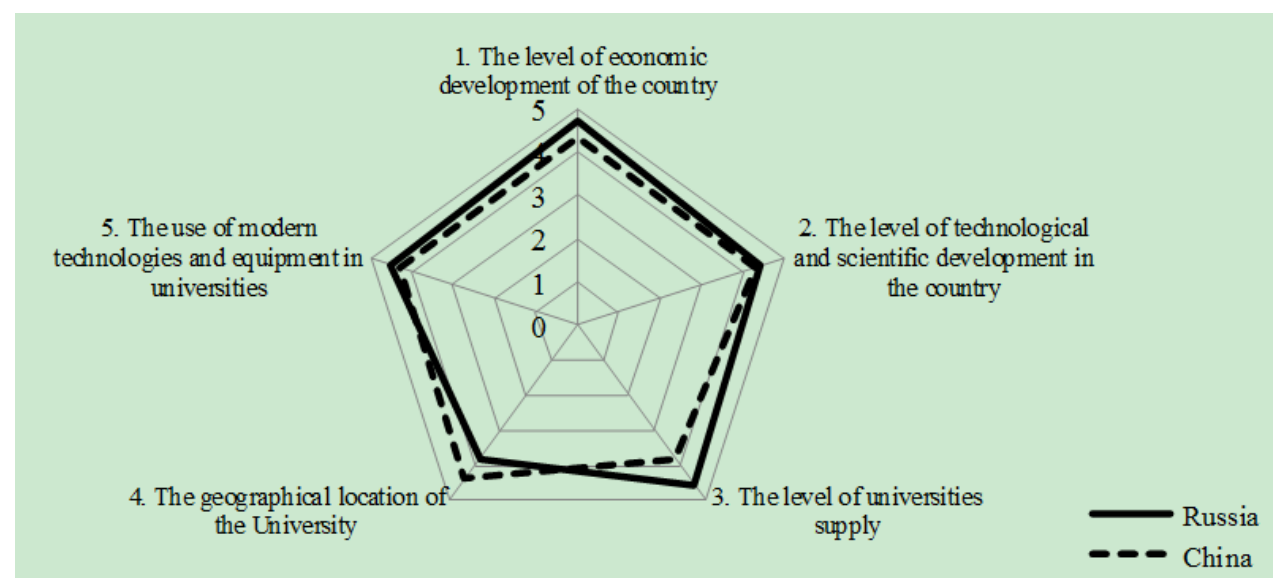

Figure 3. The distribution of the average scores of the respondents concerning the importance of the elements of the material environment in the shaping of the cultural model, authoring

The hypothesis about the fact that the model of the culture is formed under the influence of the system of cultural values, and the elements of the institutional and material environments, was completely confirmed.

To confirm the second hypothesis, the authors based on the results of the questionnaire used the method of statistical analysis, by constructing a matrix of elements contingency, which forms the model of culture, and the students' attitude to the social environment of the universities (Table 5, Table 6).

Table 5. A matrix of correspondence of the Russian students' attitude to the social environment of the universities with the elements of culture model, 2014. Authoring

\begin{tabular}{|c|c|c|c|c|c|c|c|c|c|c|c|c|}
\hline \multirow{3}{*}{$\begin{array}{l}\text { Elements of } \\
\text { the culture } \\
\text { model }\end{array}$} & \multicolumn{12}{|c|}{ Elements of the social environment of the universities } \\
\hline & \multicolumn{2}{|c|}{$\begin{array}{l}\text { Housing and } \\
\text { communal } \\
\text { infrastructure }\end{array}$} & \multicolumn{2}{|c|}{$\begin{array}{l}\text { trade and } \\
\text { public } \\
\text { catering } \\
\text { infrastructure }\end{array}$} & \multicolumn{2}{|c|}{$\begin{array}{l}\text { domestic } \\
\text { service } \\
\text { infrastructure }\end{array}$} & \multicolumn{2}{|c|}{$\begin{array}{l}\text { Cultural and } \\
\text { recreational } \\
\text { infrastructure }\end{array}$} & \multicolumn{2}{|c|}{$\begin{array}{l}\text { Sport and } \\
\text { recreation } \\
\text { infrastructure }\end{array}$} & \multicolumn{2}{|c|}{$\begin{array}{l}\text { Communicationa } \\
\text { infrastructure }\end{array}$} \\
\hline & $\mathrm{A}^{1}$ & $\mathrm{~B}^{2}$ & A & B & A & B & A & B & A & B & A & B \\
\hline Values & 4.6 & 3.9 & 4.3 & 3.5 & 3.8 & 3.3 & 4.3 & 3.5 & 4.5 & 3.4 & 4.3 & 3.2 \\
\hline $\begin{array}{l}\text { Institutional } \\
\text { environment }\end{array}$ & 3.9 & 3.3 & 3.7 & 2.9 & 3.2 & 2.7 & 3.7 & 2.9 & 3.9 & 2.8 & 3.6 & 2.6 \\
\hline $\begin{array}{l}\text { Material } \\
\text { environment }\end{array}$ & 4.5 & 3.4 & 4.2 & 3.0 & 3.7 & 2.8 & 4.2 & 3.0 & 4.4 & 2.9 & 4.1 & 2.7 \\
\hline
\end{tabular}

Discription: $\mathrm{A}^{1}$ - the importance of the indicator for the respondent; $\mathrm{B}^{2}$ - the respondents' satisfaction with the indicator

Analysis of the contingency matrix of the Russian students' attitude to the social environment of the universities with the elements of the culture model, shows a high degree of the culture elements influence on the Russian students' attitude to such elements of the social environment as housing and communal infrastructure, sports and recreational infrastructure (value of the index 3, 9-4, 6 points). The least effect the elements of the culture model have on the students' attitudes to the consumer services infrastructure of the University, this situation can be explained by the age characteristics of the studied categories of respondents. It is worth noting the existing gaps in assessing the importance of the analyzed indicators for the students and their satisfaction with these indicators (gaps 0.9-1.5 points).

Analysis of the contingency matrix of the Chinese students' attitude to the social environment of the universities with the elements of the culture model (Table 6) is significantly different from the analogous contingency matrix 
for Russian students (Table 5). The Chinese students have a high relationship between the elements of the culture model and their attitude to all elements of the social environment of the University. Moreover, indicators of the importance of the elements of social environment of the university for Chinese students are almost identical to the indicators of their satisfaction with these elements.

Table 6. A matrix of correspondence of the Chinese students' attitude to the social environment of the universities with the elements of culture model, 2014, authoring

\begin{tabular}{|c|c|c|c|c|c|c|c|c|c|c|c|c|}
\hline \multirow{3}{*}{$\begin{array}{c}\text { Elements of } \\
\text { the culture } \\
\text { model }\end{array}$} & \multicolumn{12}{|c|}{ Elements of the social environment of the universities } \\
\hline & \multicolumn{2}{|c|}{$\begin{array}{l}\text { Housing and } \\
\text { communal } \\
\text { infrastructure }\end{array}$} & \multicolumn{2}{|c|}{$\begin{array}{l}\text { trade and } \\
\text { public } \\
\text { catering } \\
\text { infrastructure }\end{array}$} & \multicolumn{2}{|c|}{$\begin{array}{l}\text { Domestic } \\
\text { service } \\
\text { infrastructure }\end{array}$} & \multicolumn{2}{|c|}{$\begin{array}{l}\text { Cultural and } \\
\text { recreational } \\
\text { infrastructure }\end{array}$} & \multicolumn{2}{|c|}{$\begin{array}{l}\text { Sport and } \\
\text { recreation } \\
\text { infrastructure }\end{array}$} & \multicolumn{2}{|c|}{$\begin{array}{l}\text { Communicational } \\
\text { infrastructure }\end{array}$} \\
\hline & $\mathrm{A}^{1}$ & $\mathrm{~B}^{2}$ & A & B & A & B & A & B & A & B & A & B \\
\hline Values & 4.5 & 4.5 & 4.4 & 4.3 & 4.4 & 4.4 & 4.5 & 4.4 & 4.5 & 4.5 & 4.4 & 4.3 \\
\hline $\begin{array}{l}\text { Institutional } \\
\text { environment }\end{array}$ & 4.5 & 4.4 & 4.4 & 4.2 & 4.3 & 4.3 & 4.4 & 4.3 & 4.5 & 4.3 & 4.4 & 4.2 \\
\hline $\begin{array}{c}\text { Material } \\
\text { environment }\end{array}$ & 4.4 & 4.3 & 4.3 & 4.2 & 4.3 & 4.2 & 4.4 & 4.2 & 4.4 & 4.3 & 4.3 & 4.1 \\
\hline
\end{tabular}

Discription: $\mathrm{A}^{1}$ - the important of the indicator for the respondent; $\mathrm{B}^{2}$ - the respondents' satisfaction with the indicator

\section{Discussion}

The scientific studies of international competitiveness of the universities originate from the researches of the scientists' who analyzed the competitiveness of educational services. At present, the understanding of educational service is being transformed; it includes not only the provided educational product, but also the characteristics of the environment in which it is provided (Barlett, 2011; Buela-Casal, 2007; deFilippo, 2012). The students' (consumers of educational services) requirements increase both for the quality of educational products, and for the social environment of the universities, this promotes not only the acquisition of knowledge, but also improving the quality of students' life during their studies at the university, and the role of the social component is reinforced with the development of the standard of living in country.

With the increased competition in the market of educational services, to increase the international competitiveness of the universities, it is necessary to take into account cross-cultural characteristics of the consumers of educational services (Agarwal, 2010; Dill, 2005; Gesteland, 2012; Hofstede, 2002). Cultural specificity of the students' behavior is a poorly-studied area of research. There are no large-scale studies that combine cross-cultural researches of competitiveness of the universities; this indicates the birth of a new vector of scientific researches.

The subject matter of the current researches in the field of international competitiveness of the universities mainly covers the construction of international universities' rankings (Buela-Casal, 2007; deFilippo, 2012; Filinov, 2002; Liu, 2005; Merisotis, 2005; Merisotis, 2005). Not enough attention is given to sorting out and analyzing the factors affecting the international competitiveness of the universities. The role of the social infrastructure of the universities in increasing their competitiveness is virtually ignored. In the present study we made an attempt to develop a methodological approach to the study of the effect of cross-cultural characteristics on students' attitudes toward the social infrastructure of the universities that makes a certain contribution to the development of theory and practice of the researches in this field. The development of further researches in this area can be designed to evaluate the quantitative and qualitative impact of the social environment of the universities on their international competitiveness, taking into account the cross-cultural aspects.

\section{Conclusion}

In this study:

1) We developed tools to analyze the impact of cross-cultural differences on the students' attitude to the elements of the social environment of the universities. 
2) We sorted out the features of the formation and construction of culture models, including a list of cultural values, elements of the institutional and financial environment, adapted to the market of educational services of individual countries in the Asia-Pacific region. Within the frameworks of cross-cultural analysis we revealed differences in the culture of China and Russia. It was found that the model of Chinese culture is largely characterized by such cultural values as health, safety, self-confidence. Distinctive cultural values of Russian students are breadth of views, development, and honesty. In the assessment of the elements of the institutional environment, the students of the analyzed cultures found significant gaps, especially in such indicators as the impact of the level of religious restrictions on the consumption and supply of educational services; it is more typical for Chinese students, to a lesser extent for Russian ones.

3) We suggest methodical tools to assess the impact of cultural elements on the students' attitude to the social environment of the universities (contingency matrix), which allowed to determine the cross-cultural gaps in the students' from different countries attitude to the social environment of the universities, which must be considered to improve the competitiveness of the universities in the educational market of Asia-Pacific countries. It was found that cross-cultural characteristics have a greater influence on the attitudes of Russian students to the housing and utilities infrastructure, sports and recreational infrastructure, and satisfaction of Russian students with the elements of the social environment of the universities is much lower than the importance of these indicators. In contrast to the Russian students, cross-cultural characteristics of Chinese students substantially affect all elements of the social environment of the universities (housing and utilities, catering and trade, consumer services, cultural and recreational, sports and fitness, communicational), and the satisfaction of Chinese students with the environment of the universities is high.

\section{Acknowledgements}

The results were achieved within the frameworks of the governmental assignment of Russian Ministry of Education and Science in the sphere of scientific research during the researching assignment \# 26.1478.2014/K "The structural transformation of Russian Economy through the integration installation in the industrial markets of Asia-Pacific Region"

\section{References}

Agarwal, J., Malhotra, N., Bolton, K., \& Ruth, N. (2010). A Cross-National and Cross-Cultural Approach to Global Market Segmentation: An Application Using Consumers' Perceived Service Quality. Journal of International Marketing, 18(3), 18-40. http://dx.doi.org/10.1509/jimk.18.3.18

Aghion, P., Dewatripoint, M., Hoxby, C. M., Mas-Colell, A., \& Sapir, A. (2010). The governance and performance of research universities: Evidence from Europe and the USA. Economic Policy, 25(61), 7-59. http://dx.doi.org/10.1111/j.1468-0327.2009.00238.x

Al-Hyari, K., Alnsour, M., Al-Weshah, G., \& Haffar, M. (2012). Religious beliefs and consumer behavior: From loyalty to boycotts. Journal of Islamic Marketing, 3(2), 155-174. http://dx.doi.org/10.1108/17590831211232564

Barlett, P. F. (2011). Campus sustainable food projects: Critique and engagement. American Anthropologist, 113, 101-115. http://dx.doi.org/10.1111/j.1548-1433.2010.01309.x

Buela-Casal, G., Gutiérrez-Martínez, O., Bermúdez-Sánchez, M., \& Vadillo-Muñoz, O. (2007). Comparative study of international academic rankings of universities. Scientometrics, 71(3), 349-365. http://dx.doi.org/10.1007/s11192-007-1653-8

Cheung, F. M., Van de Vijver, F. J. R., \& Leong, F. T. L. (2011). Toward a new approach to the assessment of personality in culture. American Psychologist, 66(7), 593- 603. http://dx.doi.org/10.1037/a0022389

deFilippo, D., Casani, F., García-Zorita, C., Efraín-García, P., \& Sanz-Casado, E. (2012). Visibility in international rankings. Strategies for enhancing the competitiveness of Spanish universities. Scientometrics, 93(3), 949-966. http://dx.doi.org/10.1007/s11192-012-0749-y

Dill, D. D., \& Soo, M. (2005). Academic quality, league tables and public policy: A cross-national analysis of university ranking systems. Higher Education, 49, 495-533. http://dx.doi.org/10.1007/s10734-004-1746-8

Dimitrova, R., Bender, M., \& Van de Vijver, F. J. R. (2014). Global perspectives on well-being in immigrant families (pp. 291-310). New York, NY: Springer. http://dx.doi.org/10.1007/978-1-4614-9129-3

Filinov, N. B., \& Ruchkina, S. (2002). The ranking of higher education institutions in Russia: Some methodological problems, Higher Education in Europe, 27, 407-421. http://dx.doi.org/10.1080/0379772022000071896 
Gelade, G. A. (2008). IQ, cultural values, and the technological achievement of nations. Intelligence, 36(6), 711-718. http://dx.doi.org/10.1016/j.intell.2008.04.003

Gesteland, R. R. (2012). Cross Cultural Business Behavior: Negotiating, Selling, Sourcing and Managing Across Cultures (p. 400). Copenhagen Business School Press.

Glänzel, W., \& De Lange, C. (2002). A distributional approach to multinationality measures of international scientific collaboration. Scientometrics, 54, 75-89. http://dx.doi.org/10.1023/A:1015684505035

Harrison, L. E. (2006). The Central Liberal Truth: How Politics Can Change a Culture and Save It from Itself. Oxford University Press.

Harvey, L. (2008). Rankings of higher education institutions: A critical review. Quality in Higher Education, 14(3), 187-207. http://dx.doi.org/10.1080/13538320802507711

Hofstede, G. J., Pedersen, P. B., \& Hofstede, G. (2002). Exploring Culture: Exercises, Stories and Synthetic Cultures. Yarmouth, Maine: Intercultural Press.

Kuznetsova, E. G. (2010). Personal values: concept, approaches to classification. Vestnik OSU, 116(10), 20-24

Li, M., Shankar, S., \& Tang, K. K. (2011). Why does the USA dominate university league tables? Studies in Higher Education, 36(8), 923-937. http://dx.doi.org/10.1080/03075079.2010.482981

Liu, N. C., \& Cheng, Y. (2005). The academic ranking of world universities, Higher Education in Europe, 30, 127-136. http://dx.doi.org/10.1080/03797720500260116

Merisotis, J. P., \& Sadlak, J. (2005). Higher education rankings: Evolution, acceptance, and dialogue. Higher Education in Europe, 30, 97-101. http://dx.doi.org/10.1080/03797720500260124

Merisotis, J. P. (2005). On the ranking of higher education institutions. Higher Education in Europe, 30, $361-363$. http://dx.doi.org/10.1080/03797720500260124

Mohrman, K. (2013). Are Chinese universities globally competitive? China Quarterly, 215, 727-734. http://dx.doi.org/10.1017/S0305741013000672

Mok, K. H., \& Cheung, A. B. L. (2011). Global aspirations and strategizing for world-class status: New form of politics in higher education governance in Hong Kong. Journal of Higher Education Policy and Management, 33(3). 161-165. http://dx.doi.org/10.1080/1360080X.2011.564998

Mok, K. H. (2014). Enhancing quality of higher education for world-class status: Approaches, strategies, and challenges for Hong Kong. Chinese Education and Society, 47(1), 44-64. http://dx.doi.org/10.2753/CED1061-1932470103

Redden, G. (2011). Religion, cultural studies and new age sacralization of everyday life. European Journal of Cultural Studies, 14(6), 649-663. http://dx.doi.org/10.1177/1367549411419977

Rodionov, D. G., Rudskaia, I. A., \& Alexandrovna, K. O. (2014). How key Russian Universities advance to become leaders of worldwide education: Problem analysis and solving. World Applied Sciences Journal, 31(6), 1082-1089.

Sankaran, K. A., \& Demangeot, C. (2011). On becoming a culturally plural consumer. Journal of Consumer Marketing, 28(7), 540-549. http://dx.doi.org/10.1108/07363761111181536

Yaşar, M., \& Paul, C. J. M. (2012). Firm performance and knowledge spillovers from academic, industrial and foreign linkages: The case of China. Journal of Productivity Analysis, 38, $237-253$. http://dx.doi.org/10.1007/s11123-011-0262-y

Yonezawa, A., Nakatsui, I., \& Kobayashi, T. (2002). University rankings in Japan. Higher Education in Europe, 27, 373-382. http://dx.doi.org/10.1080/0379772022000071850

Yousaf, S., \& Malik, M. S. (2013). Evaluating the influences of religiosity and product involvement level on the consumers. Journal of Islamic Marketing, 4(2), 163-186. http://dx.doi.org/10.1108/17590831311329296

\section{Copyrights}

Copyright for this article is retained by the author(s), with first publication rights granted to the journal.

This is an open-access article distributed under the terms and conditions of the Creative Commons Attribution license (http://creativecommons.org/licenses/by/3.0/). 